NASZA DERMATOLOGIA Online OUR DERMATOLOGY Online

Source of Support: Nil

Competing Interests: None

\section{ERNST HANHART (1891-1973) AND THE SYNDROME WHICH BEARS HIS NAME}

\author{
Ahmad Al Aboud \\ Dermatology Department, King Abdullah Medical City, Makkah, Saudi Arabia \\ Corresponding author: Dr. Ahmad Al Aboud \\ ahmadalaboud@hotmail.com
}

Richner-Hanhart syndrome (RHS) is a rare autosomal recessive disease associated with high serum tyrosine levels . RHS is caused by the deficiency of tyrosine aminotransferase enzyme (TAT) [1-5]. It is listed in Online Mendelian Inheritance of Man as (tyrosinemia type II) (OMIM \#276600). It is a disorder of amino acid metabolism which characterized by ocular changes, painful palmoplantar hyperkeratosis, and mental retardation. Serum tyrosine increases resulting in the deposition of tyrosine crystals in the cornea and in corneal inflammation [5].

It is mapped to gene16q22.2.Patient with RHS may present with complaints of bilateral photophobia and tearing, which started during the infancy period. RHS should be suspected in patients demonstrating dermatologic signs, especially palmoplantar keratosis, associated with bilateral pseudodendritic corneal lesions unresponsive to antiviral therapy [1].

Patients are often misdiagnosed as having herpes simplex keratitis. However, serum and urine tyrosine levels confirm, usually, the diagnosis. A low tyrosine and phenylalanine diet permitted good control of the disease with a complete resolution of the oculo-cutaneous symptoms in a month. The importance of an early diagnosis of this syndrome to avoid the risk of mental retardation was emphesized [3].

This syndrome is reported first by Richner [6] in 1938 and Hanhart [7] in 1947.

Dr. Hermann Richner, was a Swiss dermatologist, born September 6, 1908, Zürich [8].

Ernst Hanhart (1891-1973), was a Swiss internist and human geneticist [9] (Fig. 1). After qualifying in medicine from the University of Zurich in 1916.He worked under professors Otto Nägeli (1871-1938) and Wilhelm Löffler (1887-1972). Hanhart became interested in human genetics and became a specialist in hereditary disorders [9].

He was appointed professor at the University of Zurich in 1942 and was a founding member of the Swiss Society of Genetics [9].

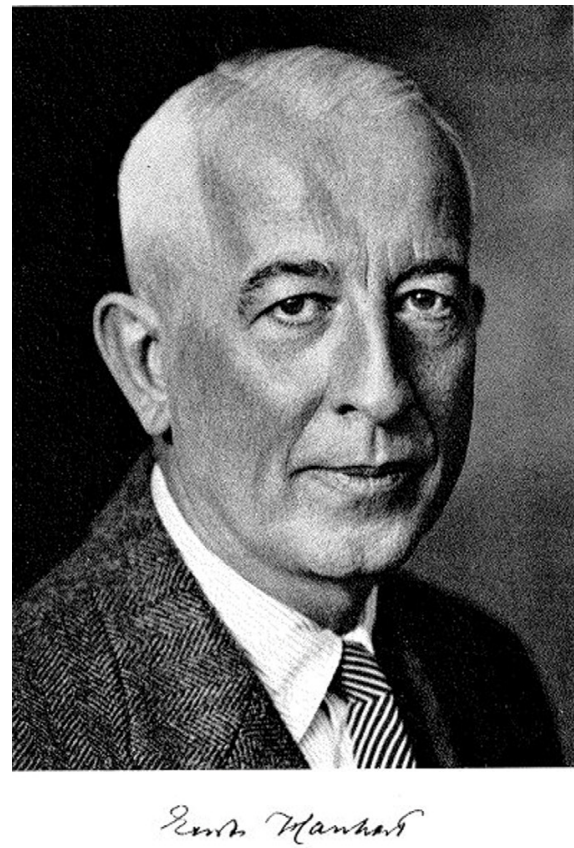

Figure 1. Ernst Hanhart (1891-1973).

Courtesy of Prof. Dr. med. Anita Rauch University of Zurich, Institute of Medical Genetics.

\section{REFERENCES}

1. Iskeleli G, Bilgeç MD, Arici C, Atalay E, Oğreden T, Aydin A: Richner-Hanhart syndrome (tyrosinemia type II): a case report of delayed diagnosis with pseudodendritic corneal lesion. Turk J Pediatr. 2011;53:692-4.

2. Culic V, Betz RC, Refke M, Fumic K, Pavelic J: Tyrosinemia type II (Richner-Hanhart syndrome): a new mutation in the TAT gene. Eur J Med Genet. 2011; 54:205-8.

3. Viglizzo GM, Occella C, Bleidl D, Rongioletti F: RichnerHanhart syndrome (tyrosinemia II): early diagnosis of an incomplete presentation with unusual findings. Pediatr Dermatol. 2006;23:25961. 
4. Rehák A, Selim MM, Yadav G: Richner-Hanhart syndrome (tyrosinaemia-II) (report of four cases without ocular involvement). Br J Dermatol. 1981;104:469-75.

5. Al-Hemidan AI, Al-Hazzaa SA: Richner-Hanhart syndrome (tyrosinemia type II). Case report and literature review. Ophthalmic Genet. 1995;16:21-6.

6. Richner H: Hornhautaffektion bei Keratoma palmare et plantare hereditarium. Klin. Monatsbl. Augenheilkd. 1938;100:580-8.

7. Hanhart E: Neue Sonderformen von Keratosis palmoplantaris, u.a. eine regelmaessig-dominante mit systematisierten Lipomen, ferner 2 einfach-rezessive mit Schwachsinn und z.T. mit Hornhautveraenderungen des Auges (Ektodermatosyndrom). Dermatologica. 1947;94:286-308.
8. Hermann Richner. A page in the internet.Whonamed it. (C) 1994 - 2012 Ole Daniel Enersen. Available online at; http://www. whonamedit.com/doctor.cfm/1222.html

9. Ernst Hanhart. A page in the internet.Whonamed it. (C) 1994 - 2012 Ole Daniel Enersen. Available online at; http://www.whonamedit. com/doctor.cfm/1223.html

Copyright by Ahmad Al Aboud. This is an open access article distributed under the terms of the Creative Commons Attribution License, which permits unrestricted use, distribution, and reproduction in any medium, provided the original author and source are credited. 